\title{
Performing Motherhood: Introduction to a Special Issue on Mothering in Children's and Young Adult Literature
}

\author{
Karen Coats $^{1} \cdot$ Lisa Rowe Fraustino ${ }^{2}$
}

Published online: 2 April 2015

(C) Springer Science+Business Media New York 2015

\begin{abstract}
This brief introduction to the essays in the special issue on mothering in children's and young adult literature spells out the dominant theme of the essays, which is the way cultural scripts, including those found in children's and young adult literature and culture, act as paratexts that condition the practice of mothering.
\end{abstract}

In 1949, Simone de Beauvoir famously declared, "one is not born, but rather becomes a woman" (1949/2009, p. 283). Gender studies has seized on this insight, working through an analysis of drag presentation and performance studies to explore the ways that femininity is a socially scripted phenomenon. Drag theory teaches us that if a man can successfully perform as a woman, then women are also performing as women in carefully structured roles that include gesture, appearance,

Karen Coats is a professor of English at Illinois State University, where she teaches children's and young adult literature. She is author of Looking Glasses and Neverlands: Lacan, Desire, and Subjectivity in Children's Literature, and co-editor of the Handbook of Research on Children's and Young Adult Literature and The Gothic in Children's Literature Haunting the Borders.

Lisa Rowe Fraustino is a professor and chair of the English Department at Eastern Connecticut State University and on the visiting faculty in the Graduate Program in Children's Literature at Hollins University, teaching both literature and creative writing courses. In addition to publishing academic scholarship on mothers, anthropomorphism, Disney, and publishing history, she has edited three collections of short fiction for young adults and authored several critically acclaimed books for young readers, including the 2010 Milkweed Prize winner, The Hole in the Wall.

$\checkmark$ Karen Coats

kscoat2@ilstu.edu

Lisa Rowe Fraustino

FraustinoL@easternct.edu

1 Illinois State University, Campus Box 4240, Normal, IL 61790, USA

2 Department of English, Eastern Connecticut State University, 83 Windham St., Willimantic, CT 06226, USA 
and affect; femininity is a masquerade, says Joan Riviere (1929), something that, according to Judith Butler (1993, p. 232), female children are "girled" into as they become adolescents. Despite this embrace of performativity with regard to becoming a woman, the discourse of motherhood still seems to cling to a more natural model: whatever she was on her way to becoming before, a woman is somehow reborn as a mother with the birth of a child. Ironically, the massive amount of literature directed to new mothers that insists that they trust their natural impulses and instincts, as well as the plethora of children's picture books that showcase a mother's steadfast love, belies any notion that mothering comes naturally. These paratexts of parenting, some meant to be read by anxious mothers and others to be shared with their children, instead offer scripts for mothers to follow in order to realize a cultural ideal, and the very fact that they exist in a state of flux - that their advice and models change over time and as children progress through childhood into adolescence-indicates that one is indeed not born, but must become a mother for her time.

The essays in this special issue look specifically at the scripts of motherhood offered through children's and young adult literature. From the public pedagogy widely disseminated through Robinson Crusoe revisions and merchandise and the ubiquitous offerings of the Disney Corporation, to the picturebooks of Anthony Browne inspired by the shifting priorities of feminism, to the ideological challenges posed by maternal boys, Other mothers, incestuous mothers, and mothers in dystopic landscapes, these essays traverse over 100 years of influential mothering scripts and their potentially productive disruptions. They invite readers to consider mothering from diverse theoretical perspectives, such as care ethics, feminism, performance studies, and cognitive narratology. Cognitive theorist Michael Burke has argued that there are four primary themes that consistently elicit an affective response in literary reading: mothers, home, childhood, and death (2010, pp. 103-106). Combining these themes, as happens more often than not in children's, middle grade, and young adult literature, packs an enormous emotional punch. And as we know, emotional engagement is key to ideological interpellation; these texts thus not only tell stories about mothers, but they also encode powerful schemas that tell us how mothering should and should not be performed in the larger world. They set our expectations of what a good mother is and does and who can perform mothering work, and while many of these scripts insist that good mothering is natural and instinctual, that insistence is undermined by the very existence of the texts which often seem to protest too much.

We would very much like to thank our reviewers for this special issue, whose careful attention and suggestions were extremely helpful throughout the revision process. These fine folk include: Evelyn Arizpe, Clare Bradford, Beverly Lyon Clark, Mary Hilton, Maria Nikolajeva, Meg Norcia, Michelle Smith, John Stephens, Liz Thiel, Eric Tribunella, and Roberta Seelinger Trites. Also, many thanks to our authors for their wonderful work, and our fabulous undergraduate assistants, Meena Roy and Laura Duquette, who are editing superstars! 


\section{References}

Burke, Michael. (2010). Literary Reading, Cognition and Emotion: An Exploration of the Oceanic Mind New York: Routledge.

Butler, Judith. (1993). Bodies that Matter: On the Discursive Limits of Sex New York: Routledge.

De Beauvoir, Simone. (1949/2009). The Second Sex. Constance Borde and Sheial Malovany-Chevallier (Trans.). New York: Vintage.

Riviere, Joan. (1929). Womanliness as a Masquerade. International Journal of Psychoanalysis, 10, 303-313. 